\title{
How does patriarchy prevent women from entering politics?
}

\author{
Kalfa Maria \\ Phd Candidate Political Science AUTH, Social Anthropologist, Gender Studies MSc, Multicultural Education MSc, \\ Management and Organization of Educational Units MSc, Social Policy in crisis situations MSc
}

\begin{abstract}
In this paper, I will show that the stereotypes about genders affect their participation in politics. How are women evaluated in politics? What role does external appearance play? Why do so few stand up for what a woman has to say and focus on what she is wearing, how beautiful she is, what her sexuality is, what about her role as a husband or mother? Society values beauty in relation to women in a way that tends to present it as the best quality. When a woman ultimately succumbs to the demands of society, she is characterized as naive, stupid, superficial, while when she disobeys she is again criticized as 'this is not a woman' and various such cosmetics for women who do not meet the expectations of 'ideal' beauty and 'ideal' femininity. If a male politician does not meet the standards of beauty of a society, there is no problem, but if a female politician does not respond, a culprit who ignores studies, experience, capacity, consistency, etc., erupts and focuses exclusively on her external features. How does this categorization relate to the expectations we have of women and how can that change?
\end{abstract}

Keywords: politics, gender, biases, authority 


\section{HUMANITIES AND SOCIAL SCIENCE}

18 - 20 September, 2020

\section{Constructing the difference}

How is the difference constructed? What factors influence this process? "The term biological sex refers to the biological differences between males and females: the visible difference of the genitals and the consequent difference in their reproductive functions; while gender refers to culture and social categorization into 'male' and 'female'»(Laqueur, 2003: 10). The categorization into male and female, in addition to the fact that it is problematic, cultivates discrimination from an early age, where growing up as a boy or girl one learns to take for granted all these cultural elements that organize the Word around gender. The dipoles constructed by culture seem to work suffocatingly and magnify when imbued with hate speech and identification with the inhuman. "According to Guillaumin, it is culture that constructs 'natural' differences" (Laqueur, 2003: 16). "Butler, based on Foucault's theory of Discourse, argues that gender is the result of discourse and biological sex is the result of gender" (Laqueur, 2003: 18). Through these Discourses, the biological sex is often involved with the social and the biological basis, ie the genitals that one has are enough to indicate behaviors, desires, needs and characters. More specifically, "since the early 70's militant feminist theorists have raised the issue of the relationship between women as a social class and the dominant cultural context" (Vitsilaki (b), 2011: 27) Since words are important and often convey meaning or construct the truth, it is important to dwell on who is speaking this truth. "The representation of the world, like the world itself, is the work of men; they describe it with their own point of view, which they confuse with the absolute truth" (Perez, 2019).

How is gender constructed? What is the position of the body in relation to gender? "Femininity is a concept that does not really exist" (Doulkeri, 1994: 16). The myth of femininity seems to function as a Western model of female behavior. Gender as well as femininity are built, they do not pre-exist. An important concept for understanding this thinking is the role that socialization plays. During socialization we acquire basic skills such as speaking, walking, etc. so with socialization we acquire the appropriate behavior by gender. This process continues in the secondary socialization bodies, most importantly the school. If a girl is aggressive she is a 'boy', if a boy is aggressive he is 'in nature'. This is how action frameworks and appropriate gender behaviors are built during socialization. Prohibitions and incitements shape boys and girls with different behavior and character. The more conservative the environment, the more it refers to gender behavior, the greater the child's adaptation to gender norms. "The biological reality of gender is merged with the interpretation that society and culture give to this reality, and thus they produce exactly the executive -in Greek we would say the created, built- gender" (Koliri, 2017: 45). Gender seems to be an unwritten tableau that culture, primary and secondary prohibitions seem to capture what is good and what is bad based on gender on the basis of prohibitions, taboos and rules. "Movements, choices, postures, explicit and implicit commands, rewards gradually create a framework, an atmosphere in which we all impersonate the gender we have previously narrated to ourselves" (Koliri, 2017: 47). 


\section{HUMANITIES AND SOCIAL SCIENCE}

18 - 20 September, 2020

\section{Gender and beauty}

Gender ambitions are formed from a very young age. These ambitions tend to determine the way a person sees himself, but also the way others see him. Typical is the example of beauty in girls and how important this value is for their future. Beauty as a good is evaluated positively for girls from a young age, even if there are other virtues such as intelligence, creativity, etc. "The ideal woman (in classic fairy tales) appears trapped in a single equivalent, a good woman = beautiful + passive figure, which ends in the same implication always, a 'good'-rich marriage "(Giannikopoulou, 2011: 189). This author characteristically mentions "in the attempt to trace the female profile in classic fairy tales, even in their illustrated dimension, we initially 'stumble' on beauty, perhaps the biggest taboo" (Giannikopoulou, 2011: 190). Society values beauty in relation to women in a way that tends to present it as the best quality. When a woman finally succumbs to the demands of society, she is characterized as naive, stupid, superficial, while when she disobeys she is criticized again as 'this is not a woman' and various such cosmetics for women who do not meet the expectations of 'ideal' beauty and 'ideal' femininity. If a man politician does not meet the beauty standards of a society, there is no problem, but if a woman politician does not meet, a culvert erupts that ignores studies, experience, capacity, consistency, etc. and focuses exclusively on its external characteristics. According to Papagiannopoulou, 2009: 26): "the following references to the non-selection of women as candidates for Parliament and local government come from members of different selection committees of British Political Parties in the 1980s:

1. She is very beautiful, voters will not take her seriously!

2. It is very old (the candidate was around 50)

3. She is very young, she can get pregnant!

4. Better to go home to take care of her children!

5. He wears many rings

6. Workers will not vote for a woman!

When a woman was nominated for President of the Republic of Greece in 2020, who finally took office, the comments below the news were the least disappointing. Comments such as:

1. Get a woman candidate for President of the Republic to play.

2. I find her sexy.

3. Looks like the Harry Potter owl.

4. The next pot.

5. An indifferent candidate for a useless position.

6 . The one who chose the photo definitely likes it?

7. Hahahahaha

8. What favors has he done to them?

9. Ust sicham. 


\title{
HUMANITIES AND SOCIAL SCIENCE
}

\author{
18 - 20 September, 2020
}

10. Let us hope a woman behaves like a man because the presidents so far have been behaved as women.

11. Where are you going with such a look?

These comments condense the stereotypes that are often reproduced about women politicians. These comments are about appearance, the ability to take a position, sexuality and how it is used to take a position. Also, the phrase "What favors has he done to them" suggests that a woman can not take a position meritoriously due to qualifications, etc., but because she is beautiful or has done sexual favors. While the phrase 'Let a woman hope to behave like a man because the presidents until now were women', the term man becomes indicative of virtues such as honesty, straightforwardness, etc., while the term 'women' is used disparagingly to indicate cowardice, cunning, etc. By this logic a woman must behave like a man in order to be effective, assuming that the aforementioned virtues are an acquis of men. "The woman must be beautiful, since she always becomes the object and never the subject of observation" (Giannikopoulou, 2011: 190). The comments spark the candidate not because of the qualifications she has or not, but because of her appearance, which does not meet the beauty standards that society has constructed. It is noteworthy that if in the end a woman politician meets the Western standards of beauty, the sabotage starts again from her beauty, which she used as a weapon and her sexuality, which she also used to be there! "If beauty is the main feature of external appearance, passivity claims the same enviable position in the female personality and is projected in the fairy tale through two main situations that function symbolically: a) the inability to speak and the endless sleep on the other" (Giannikopoulou, 2011: 191). Women who show an active attitude, speak decisively and loudly are also negatively characterized as androgynous, 'iron' (that is) tough women, etc.

\section{Woman's social roles}

The different social roles by gender are cultivated throughout life and largely determine the different point of view of reality by each gender. "Learning stereotypes about different gender roles starts at an early age. In the first stage the boys learn that they differ from each other in appearance, then they learn that other activities are done by the boy and others by the girl and then that both genders have different abilities; at school age the learning of the different 'destination' continues '»(Doulkeri, 1994a: 15). The toys, the colors chosen, the clothes, the kinesiology make clear the boundaries between a girl and a boy, establishing prohibitions and consequences for anyone who violates the limits and plays with their gender. These boundaries become clear in the context of the school environment, for example girls who play with boys or prefer football are 'boy girls' etc. But why does this happen and how restrictive is it for children, but also for adults and ultimately for all genders who are pressured by society to obey the man / woman dipole? Why should activities have sex? Why should football be considered a man and ballet a woman? These questions unfold the way public opinion approaches gender and the constraints it raises. We must also not forget that: "both positive and negative stereotypes are equally dangerous" (Natsi \& Papa, 2019: 14). 


\title{
HUMANITIES AND SOCIAL SCIENCE
}

\author{
18 - 20 September, 2020
}

But how do cultural Discourses reproduce power relationships? That "women 'as well as' men' are not a biological genus, but a social sex, constructed historically, socially and culturally. Gender is now emerging as a social relationship and a cultural symbol, capable of shaping power relations "(Avdela \& Psarra, 1997: 11). These cultural Discourses construct dipoles, which categorize the abilities, inclinations and features of the genders. "Since the 18th century, the notions of male 'energy' and female 'passivity' have been emerging" (Laqueur, 2003: 12). "Freud rejects the equation of 'active' with the masculine and 'passive' with the feminine... although he regularly falls into it... while Lacan does not let us forget that gender differentiation takes place in language and culture, which they exist before the individual, they include and transcend the micro-social events of the family "(New, 1991: 7-10). But is that so? Aren't culture and language derivatives of society? What contributes to the development of language? Clearly language, according to sociolinguists, is not static, but is in constant interaction with the environment. This interaction explains the linguistic changes that follow or presuppose social changes. As Riley point out, life is not an evolution from the biological to the social ... even in the womb, the infant has a place in society, and in the process through which he becomes a conscious participant; social relations begin at birth»(New, 1991: 15).

The mentality not only of men but also of women has contributed to the perpetuation of unequal power relations and the perpetuation of gender inequalities. The Discourse shaped and greatly influenced the upbringing of the children, who -essentially- reproduced what they had learned to take for granted. What is worse is the gender biases. If we look back at philosophy, science and everyday life, as portrayed in the media and on television, map the images of an era that shattered women's freedom. The institution of dowry, virginity, the identification of women with the home, the almost prohibitive presence in public space limited for years the female identity in Greece. A typical example is the marriage between a minor and an adult, which in the western societies is now characterized as pedophilia, which is prosecuted, while our grandmothers and great-grandmothers were married under these conditions with consulate, dowry, dowry, virginity and at a young age, not having a 'voice' in their marriage, in their body, in their life. There is a lot of discussion about children getting married at a very young age in non-Western societies. However, although such a relationship is treated here as pedophilia, we often see that there are still commonalities with countries that treat women as not free to decide on their own body. In the western world, you wear what you want, but if you get something you are blamed for what you wore and for the time you were walking in the street. Although people are beginning to realize the basic differences, we often see outbursts of hatred and ugly descriptions of women who 'went looking'. These perceptions continue to act as weights and undermine the freedom of women around the world. Clothing choices and opening hours continue to affect the way many women think, which limits their freedom. Body recovery and body moves were not accidentally put on the feminist agenda, as for many years women had no 'voice' in either their own bodies or their own lives. 


\section{HUMANITIES AND SOCIAL SCIENCE}

18 - 20 September, 2020

\section{How does patriarchy affect women's access to public space and politics?}

How do gender Discourses relate to patriarchy? "Feminist sociologists often use this term - of patriarchy - arguing that patriarchy is manifested not only in family power relations, but also in the general set of social arrangements that serve to establish that men remain in control and women remain submissive" (Hall \& Gieben, 2003: 265) Patriarchy structures family, professional and financial relations, a fact that makes it difficult for women to advance. A typical example is that of the 'glass ceiling', which adversely affects the opportunities that women have for professional and economic development. Can we talk about democracy when women cannot participate in politics? Can democracy exist when women are treated as second-class citizens? Are laws and decrees enough to ensure women's access to politics? How effective is quota practice? How difficult is it to recognize gender Discourses when they act indirectly and often unconsciously for all genders? According to Halkia (2018: 11) "no definition of 'democracy' can be upheld in a society when some people are not fully recognizable as human beings and systematically accept discrimination and various forms of violence." How does feminism relate to politics? For Vicky Randall, feminism is "a political approach, in the sense that it highlights the fundamentally political relationship between gender and power" (Makris, 2015: 31). Judith Evans distinguished three major feminist categories: the liberal, the marxist, and the radical (Evans 1986: 103). There are people who argue that they do not behave sexistly or that they do not adopt similar practices while doing so. Regularity, which is based on what has been acquired through upbringing and social interaction, is influenced by sexism, where in the end sexist behaviors and practices are not perceived as such. This normalization is perhaps one of the most important obstacles, which prevents us from seeing how a behavior defined as sexist can create a big problem, create obstacles and reproduce that behavior. A typical example is the way that most women voted, not having their own reason, but essentially reproducing the views and desires of their husbands. For most of these women, this practice was taken for granted. "Thus in the mid-nineteenth century, Marshall argued that 'political rights had come into the possession of men and women's political rights, where they were considered to be included and represented by their male relatives, while their rights to exercise what we now see them as fundamental civil liberties challenged in the courts as they fought to be recognized as 'persons' '(Summers, 1991: 21). Granting women rights, however, was the beginning of claiming further issues that undermined their freedoms and, consequently, their choices and their own lives. Another fact becomes important, the issue of the non-existence of women in political life. The pressures exerted by these women, the first feminists, started from the streets and the mobilizations outside official bodies. This detail is important, as there was no person available within the policy who could support their rights. This highlights the importance of the presence of social movements and bottom-up politics in exerting pressure and pursuing rights. 


\section{HUMANITIES AND SOCIAL SCIENCE}

18 - 20 September, 2020

\section{Reflections-actions}

It is worthwhile to dwell on the reasons why women stay out of the political arena and to enter the process of building a new worldview and a new way of socializing.

According to Papagiannopoulou (2009: 21), factors that act as a deterrent to women's participation in politics are the following:

1) Cultural traditions and attitudes

2) The social norms

3) The money

4) Trust issues

5) The permanent lack of time

6) Career obstacles

But what could be done? In addition to the changes and the reflection of the perceptions that concern the abilities and the possibilities of the genders, actions could be implemented, which will practically support any changes.

"Women's NGOs and political councils can:

1) put pressure on the introduction of gender equality quotas

2) Encourage more women to be active in all areas of politics and public life

3) To train the candidates and the groups that support them in their campaigns

4) To create demand in the labor market for women

5) To help change the social norms that exists in public life and politics

6) To make women aware of their rights and responsibilities as citizens

7) To raise money for the candidates (Papagiannopoulou, 2009: 25)

\section{Bibliography}

Avdela, E. \& Psarra, A. (1997). Foreword To E. Avdela \& A. Psarra (eds) Silent stories: Women and Gender in historical narrative. Athens: Alexandria Publications, pp. 9-13

Vitsilaki, Ch. (2011). INTRODUCTION: Culture (ies) -Feminism (ies): Conceptual Clarifications, Social Boundaries In Ch. Vitsilaki, M. Gasouka, G. Papadopoulos (ed.) Gender and Culture. Athens: Interaction, pp. 9-23

Cameron, D. (2018). Feminism: past and present of a movement. F. Ditsas (trans.). Athens: University Publications of Crete 


\section{HUMANITIES AND SOCIAL SCIENCE}

\section{8 - 20 September, 2020}

Giannikopoulou, A. (2011). 'And they lived well and we lived better': Positions and counterpositions for the woman of the illustrated fairy tales In Ch. Vitsilaki, M. Gasouka, G. Papadopoulos (ed.) Gender and Culture. Athens: Interaction, pp. 189-216

Doulkeri, T. (1994). Gender equality in labor relations. Athens: Papazisis Publications

Doulkeri, T. (1994a). Child media and Sexism. Athens: Papazisis Publications

Hall, S. \& Gieben, B. (2003). The formation of modernity: Economy, Society, Politics, Culture. Athens: Savvalas

Kolyri, Ch. (2017). Gender as bait: Psychoanalysis, Politics and Art. Athens: Patakis Publications

Laqueur, T. (2003). Constructing gender: Body and social gender from the ancient Greeks to Freud. Athens: Polytropon Publications

Makris, S. (2015). Feminism and Democracy: From Mary Wallstonecraft to Judith Butler. Thessaloniki: Eneken

Natsi, D., Papa, Th. (2019). The legislative treatment of gender discrimination in Greece. Thessaloniki: Heinrich Boll Stiftung

New, C. (1991). Women's Oppression in the world and in Ourselves: a Feminist look at feminism and psychoanalysis In

Papagiannopoulou, M. (2009). Instructor / Three Handbook: Communication Skills for Women in Politics - Equal Participation in Decision-Making Centers: Women at the Heart of Europe. Athens: KETHI

Perez, C. Caroline (2019). Invisible women: Prejudices and discrimination in a world for men. K. Gouleti, V. Misiou (transl.). Athens: Metaichmio

Summers, Y. (1991). Women and citizenship: The Insane, the Insovent and the Inanimate. In P. Abbott \& C. Wallace (edit) Gender, Power \& Sexuality, p.p.19-40 